\title{
Reality of Dental Implant Surface Modification: A Short Literature Review
}

\author{
In-Sung Yeo*
}

Department of Prosthodontics and Dental Research Institute, Seoul National University School of Dentistry, Seoul, Korea

\begin{abstract}
Screw-shaped endosseous implants that have a turned surface of commercially pure titanium have a disadvantage of requiring a long time for osseointegration while those implants have shown long-term clinical success in single and multiple restorations. Titanium implant surfaces have been modified in various ways to improve biocompatibility and accelerate osseointegration, which results in a shorter edentulous period for a patient. This article reviewed some important modified titanium surfaces, exploring the in vitro, in vivo and clinical results that numerous comparison studies reported. Several methods are widely used to modify the topography or chemistry of titanium surface, including blasting, acid etching, anodic oxidation, fluoride treatment, and calcium phosphate coating. Such modified surfaces demonstrate faster and stronger osseointegration than the turned commercially pure titanium surface. However, there have been many studies finding no significant differences in in vivo bone responses among the modified surfaces. Considering those in vivo results, physical properties like roughening by sandblasting and acid etching may be major contributors to favorable bone response in biological environments over chemical properties obtained from various modifications including fluoride treatment and calcium phosphate application. Recently, hydrophilic properties added to the roughened surfaces or some osteogenic peptides coated on the surfaces have shown higher biocompatibility and have induced faster osseointegration, compared to the existing modified surfaces. However, the long-term clinical studies about those innovative surfaces are still lacking.
\end{abstract}

Keywords: Anodic oxidation; BMP; fluoride; functional peptide; hydrophilicity; implant surface; SLA; surface modification.

Surface characteristics are one of six key factors that determine the long-term success of dental implants [1]. Screw-shaped endosseous implants that have a turned surface of commercially pure titanium (cp Ti) have shown successful long-term (more than 10 years) clinical results in single and multiple restorations [2-4]. However, a turned cp Ti surface generally requires a long time to establish because the bone needs to heal and biologically attach to the surface. Clinically, this means a patient would have a long edentulous period before his/her implant is loaded, or before implantsupported restoration. By modifying the characteristics of the $\mathrm{Ti}$ surface, biocompatibility can be improved, faster osseointegration can be provoked, and the edentulous period of a patient can be finally shortened [5-8].

Roughening the cp Ti surface induces an excellent bone cell response to the surface $[9,10]$. A surface is roughened by blasting, which involves particles consisting of $\mathrm{TiO}_{2}$, $\mathrm{Al}_{2} \mathrm{O}_{3}$, or other substances hitting the surface at a certain pressure to produce irregularities, by acid etching, or by a combination of blasting and acid etching (SLA). Such a blasted or etched surface is considered to be changed mainly

*Address correspondence to the author at the Department of Prosthodontics and Dental Research Institute, Seoul National University School of Dentistry, 101 Daehak-ro, Jongno-gu, Seoul 110-749, Korea;

Tel: +82-2-2072-2661; Fax: +82-2-2072-3860; E-mail: pros53@snu.ac.kr in topographical aspects, while surface treatment methods alter both the topography and chemistry of an implant surface [6]. Superior histomorphometry and stronger bone responses have been found on roughened surfaces compared to turned surfaces [11-13]. An acid etched surface was reported to show four times greater resistance to removal torque, the measurement of which has been one of the tools evaluating the quality of binding at the interface between the bone and the implant surface, than the turned cp Ti surface in an experiment using the screw-shaped implants and the distal rabbit femurs [11]. A roughened surface by sandblasting also displayed a significantly higher bone contact than the turned surface in another previous study, which especially described that new bone was grown from the sandblasted surface to the old bone, while the bone was formed from the old bone to the turned surface [12]. Topographically modified $\mathrm{Ti}$ surfaces are reported to show high success rates in clinical trials. A split-mouth experimental design found no failure in SLA implants, when these implants were early loaded at 6 weeks after implant insertion into patients' jaws [14]. This previous study was a randomized-controlled, double-blind investigation with 5-year prospective results, which is known to have a very high evidence level [14]. In addition, the optimal roughness $\left(\mathrm{S}_{\mathrm{a}}\right.$ of about $\left.1.5 \mu \mathrm{m}\right)$ of such surfaces that can elicit the maximum bone response has been investigated [15-17]. 
Anodic oxidation on the Ti implant surface increases not only the roughness of the surface but also the thickness of the Ti surface oxide, which is important for the biologic bone response $[6,18]$. This type of surface shows more favorable bone responses than turned smooth Ti surfaces [13, 19, 20]. In a study evaluating the human jawbone response to the oxidized $\mathrm{Ti}$ surface, histomorphometry resulted in significantly more favorable bone response (higher bone-toimplant contact) to the oxidized $\mathrm{Ti}$ surface at both the maxilla and the mandible, compared with the turned $\mathrm{Ti}$ surface [19]. A previous animal study using mini-pigs concluded that the anodized surface had a bone biocompatibility level similar to the hydroxyapatite coated surface, and higher than the turned surface [20]. Several clinical trials report that oxidized Ti surfaces are functional and effective on implants in the human jaw bone [21, 22]. A 5 -year prospective clinical study showed that a slightly tapered, screw-shaped $\mathrm{Ti}$ implant with the oxidized $\mathrm{Ti}$ surface could be very successful even in poor bone quality [21]. A randomized controlled clinical trial compared the clinical outcomes between the anodized and turned surfaces, demonstrating that both surfaces were affirmative although this trial was a pilot study with the relatively short, 3-year results [22]. Many authors have studied the mechanical and chemical factors that influence the $\mathrm{Ti}$ oxide layer and the bone response, which include the density during the anodic oxidation process, the electrolyte concentration, and the oxide crystal structure [23-26]. However, while the topography of an oxidized surface is completely different from that of a blasted or etched surface, anodic oxidation methods are not thought to alter the Ti surface in such a way as to provide stronger osseointegration, compared to $\mathrm{Ti}$ surfaces that are optimally roughened by blasting and/or etching (Fig. 1) [13, 27, 28]. Anodic oxidation itself is considered to have a limitation in bone response from the results that an electropolished (very smooth) Ti surface tends to decrease bone formation rate despite that the surface is anodized [18]. Neither the removal torque test nor the histomorphometric measurement revealed any significant difference between the anodized and the blasted surfaces in a study with a non-loaded model using the rabbit tibia [13]. A

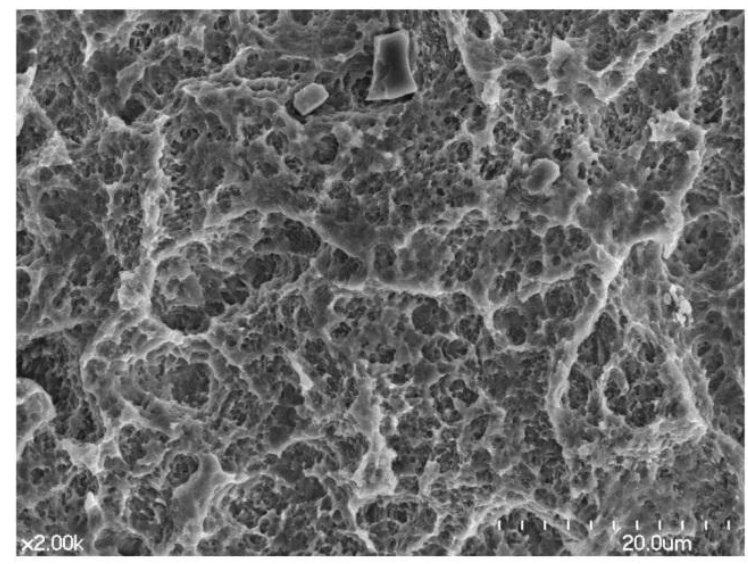

(a) previous study with a loaded model using the beagle dog found no significant difference in histomorphometry between the anodized and the SLA surfaces [27]. Also, another prior study with the non-loaded rabbit tibia model showed no significant differences in the biomechanical tests including removal torque between those two surfaces (the anodized surface and the SLA surface) [28].

Certain surface modifications have some chemical effects, which are added to the physical and topographical effects and are considered to make osseointegration stronger than the roughening procedure only, on bone responses. Calcium phosphate-coated surfaces have been used for dental implants since the mid-1980's because of their similarity to bone mineral [29, 30]. Various forms of calcium phosphate like hydroxyapatite, as well as various coating methods, have been previously investigated [13, 31-35]. Clinically, calcium phosphate-coated implants have been reported to be functional in patient jaws in the long-term [36, 37]. However, one meta-analytic study, investigating the survival analysis studies, reported that the 5 to 8 year cumulative survival rates of hydroxyapatite coated implants were evaluated to range from $79.2 \%$ to $98.5 \%$, which are not considered to be as reliable as implants with the roughened Ti surfaces [36]. Another meta-analytic study concluded that long-term clinical data on calcium phosphate-coated implants were very limited, irrespective that the annual failure rate was estimated not to increase progressively, and that the cumulative survival rate was considered to be similar to that of uncoated implants [37]. Furthermore, there are major concerns with such coating, including coating delamination, cohesive failures of the coating layer, and adhesive failures between the calcium phosphate coating and the Ti implant [30, 34]. Although fast bone response to the calcium phosphate-coated surface and its similarity to bone mineral lead to the possibility of its application to some extreme cases like osteoporotic patients, such an application needs more studies including clinical trials [31]. Another example of chemical modifications is a fluoride-modified surface, which is made by reducing the Ti surface on a cathode to attract the cation, fluoride ion, in a hydrofluoric acid solution [38]. Adding fluoride treatment to titanium

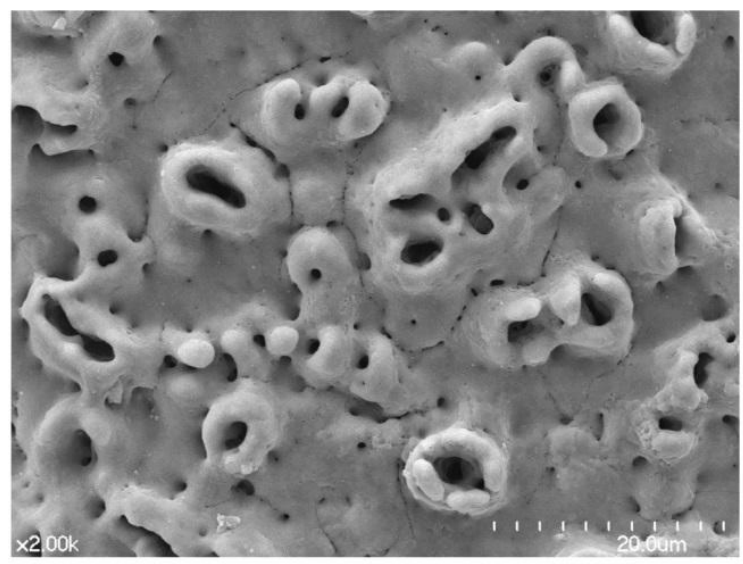

(b)

Fig. (1). Scanning electron microscopic images $(\times 2000$ magnification) of a sandblasted, large-grit, acid-etched (SLA) Ti surface (a) and an anodized Ti surface (b). Note that the SLA surface mainly displays a honeycomb-like structure while the anodized surface shows a craterlike structure. 
dioxide $\left(\mathrm{TiO}_{2}\right)$ grit-blasted cp Ti surface results in a superior bone response to that of $\mathrm{TiO}_{2}$ grit-blasted cp Ti surface [3841]. Low concentration of hydrogen fluoride etching on $\mathrm{Ti}$ surface was reported to enhance the binding between the bone and the surface considerably [38]. The fluoride modification added to $\mathrm{TiO}_{2}$ grit-blasted cp Ti surface showed improved osteoblastic differentiation in vitro and increased bone formation in vivo [39]. A previous study with the rabbit tibia model demonstrated that fluoride modification had positive effects on bone responses by indicating the increased gene expression levels of some osteogenic markers like osteocalcin, and the higher bone mineral densities around the fluoride-modified Ti surfaces [41]. In addition, in clinical studies, fluoride-modified Ti implants were found to be successful during 3-5 year follow-up periods [42-44]. The survival rate of a fluoride-modified implant was estimated to be about $96 \%$ when the implant was loaded immediately after insertion into the patient's mouth, which is considered a fairly excellent result [42]. Both immediately and early loaded implants had high survival rates of about $97 \%$ after 5 years in another previous prospective study [43].

Anodized, calcium phosphate-coated, and fluoridemodified Ti surfaces, which use advanced chemical modifications and are presently widespread in the market, result in increased affinity to osteoblasts as well as faster and stronger in vivo osseointegration than turned $\mathrm{cp}$ Ti surfaces $[18,19,31,34,38,39]$. However, little difference, especially at the in vivo level, has been found in bone response between these chemical effect-added $\mathrm{Ti}$ surfaces and the topographically modified $\mathrm{Ti}$ surfaces (the blasted, the acidetched, or the SLA Ti surface) [13, 28, 32, 45-49]. In a previous study with the non-loaded model using the rabbit tibia, neither the anodized nor the calcium phosphate-coated surface found any significant difference in the initial in vivo bone response, compared with the blasted surface [13]. Other studies using such a rabbit tibia model revealed no significant difference either in removal torque or in bone-toimplant contact, when those studies compared the anodized surface with the SLA surface [28, 32]. There were no significant differences in the histomorphometric results, irrespective of the types of animals (rabbits or dogs) used in other previous studies, when the fluoride-modified surface was compared with the anodized surface or when the fluoride-modified surface was compared with the SLA surface $[45,46]$. A 5-year prospective clinical study indicated that the cumulative survival rate of an anodized implant was similar to that of an SLA implant [47]. The lack of conclusive results may be due to incomplete randomization of animal groups, heterogeneity of animals, small sample size (in both human and animal studies), and various observation time periods of animal studies. However, no chemical aspect of such modified surfaces is considered to have a strong effect on the bone response under a biological system, overwhelming the effect of the physical property like surface roughness.

The hydrophilicity of an implant surface was recently investigated and is thought to be an important factor in the enhancement of the bone response [50-52]. Several studies have evaluated the biocompatibility of an SLA surface with additional modifications aimed to increase hydrophilicity [53-55]. These studies indicated that such a hydrophilic SLA surface promotes bone formation and shows increased osteogenic potential, when compared to its predecessor, an SLA surface with no modifications to hydrophilic properties [53-56]. The hydrophilic SLA surface was reported to have a positive influence on early bone response in a previous study that used dogs, showing higher bone-to-implant contact than the conventional, non-hydrophilic SLA (hydrophobic SLA) surface [53]. Similar results were also found in another study using miniature pigs [54]. An in vitro experiment with human bone marrow-derived mesenchymal stromal cells showed higher gene expression levels of the osteogenic markers like runt-related transcription factor 2 (RUNX2) and bone sialoprotein (BSP) on the hydrophilic SLA surface [55]. The authors of those studies interpreted the data to indicate that hydrophilicity improves biocompatibility of the SLA surface to the implant during osseointegration [53-56]. At the in vitro level, bone cell adhesion is higher on the hydrophilic SLA surface than on the anodized or calcium phosphate-coated surface [57]. However, in vivo studies are difficult to find significant differences in bone responses between the hydrophilic SLA and other surfaces, except the studies comparing the hydrophilic SLA with its predecessor (hydrophobic SLA) [58-60]. The hydrophilic SLA surface showed statistically similar bone-to-implant contact and removal torque results in the previous animal experiments using dogs, compared with the anodized surface [58, 59]. Furthermore, the comparison clinical studies have reported that both the hydrophilic and hydrophobic SLA surfaced implants are well functional with high survival rates in patients' mouths [61, 62]. And most of the clinical studies investigating the effectiveness and maintenance of the hydrophilic SLA implant are conducted over 1-2 years of follow-up, which are just short-term results [61-66].

Currently, studies focus on evaluating the effects of organic compounds such as proteins and peptides used to coat surfaces on the biological environment of the implant [67-70]. Bone morphogenetic proteins have been used on implant surfaces to promote bone formation [67]. Recombinant human bone morphogenetic protein 2 (rhBMP2) coated on an oxidized $\mathrm{Ti}$ surface enhanced the bone affinity and healing capacity of the surface, compared with the oxidized Ti surface only [67]. Furthermore, several short peptides, derived from cell adhesion proteins, have been effective in bone cell attachment and are non-antigenic to implant surfaces [70, 71]. Both in vitro and in vivo experiments show promising results in terms of biologic responses surrounding protein or peptide-coated implants $[71,72]$. A laminin-derived peptide showed the increased expression of the osteogenic markers at the gene level, the enhanced alkaline phosphatase activity at the protein level, the improved attachment and spreading of osteoblast-like cells, and the accelerated bone response in the rabbit tibia model [71]. Stronger osseointegration to the rhBMP-2 coated implant was also confirmed in another previous study with a sheep iliac model [72]. However, other studies found no such effects around the protein- or peptide-coated implants although the osteogenic protein was indirectly delivered to the local environment via the gene of the osteogenic protein or a carrier molecule [73, 74]. Furthermore, to date, no clinical trials have been published that investigate the 
maintenance or effectiveness of such organic compoundcoated implants.

The base material for the abovementioned modifications is Ti. Other, materials, such as zirconia or Ti- zirconium alloy, are being developed and tested for dental implants [75, 76]. The types of surface modifications that can be applied to such implants seem limited at present. Blasted zirconia, calcium phosphate-coated zirconia, and hydrophilic SLA Tizirconium-alloyed implants have been evaluated in vivo and compared to surface-modified Ti implants. Evidence is lacking to show that these new implants are more biocompatible during osteogenesis and osseointegration than the currently used surface-modified Ti implants [76-78].

\section{CONCLUSION}

Ti implant surfaces have been modified in various ways to increase bone formation around the implant, to increase the healing capacity of the bone tissue, and to decrease the edentulous period of a patient. Clearly, modified surfaces demonstrate faster and stronger bone responses than $\mathrm{cp} \mathrm{Ti}$ turned surfaces. However, many of the chemically advanced surfaces, which are known to have additional chemical effects for active bone responses, fail in showing significantly superior in vivo osseointegration and osteogenesis, compared to the existing roughened surfaces that are topographically modified to obtain optimal roughness by blasting and acid etching. Also, very rare clinical studies have been found reporting significant differences in implant survival, comparing the implants with different surface characteristics. Numerous studies have investigated the effects of surface hydrophilicity and coated functional osteogenic proteins and peptides on enhanced bone formation and healing around an implant, showing the excellent results of biocompatibility in both in vitro and in vivo experiments. However, further clinical studies are needed.

\section{CONFLICT OF INTEREST}

The authors confirm that this article content has no conflict of interest.

\section{ACKNOWLEDGEMENTS}

This work was supported by the Basic Science Research Program through the National Research Foundation of Korea, funded by the Ministry of Science, ICT and Future Planning (2011-0007662). The author certifies that there is no conflict of interest with any financial organization regarding the material discussed in the article.

\section{REFERENCES}

[1] T. Albrektsson, P. I. Branemark, H. A. Hansson, and J. Lindstrom, "Osseointegrated titanium implants. Requirements for ensuring a long-lasting, direct bone-to-implant anchorage in man," Acta Orthop. Scand., vol. 52, pp. 155-170, 1981.

[2] M. Dierens, S. Vandeweghe, J. Kisch, K. Nilner, and H. De Bruyn, "Long-term follow-up of turned single implants placed in periodontally healthy patients after 16-22 years: radiographic and peri-implant outcome," Clin. Oral Implants Res., vol. 23, pp. 197204, Feb. 2012.

[3] N. Ravald, S. Dahlgren, A. Teiwik, and K. Grondahl, "Long-term evaluation of Astra Tech and Branemark implants in patients treated with full-arch bridges. Results after 12-15 years," Clin. Oral Implants Res., vol. 24, pp. 1144-1151, Oct. 2013.

[4] G. A. Zarb and A. Schmitt, "Osseointegration and the edentulous predicament. The 10-year-old Toronto study," Br. Dent. J., vol. 170, pp. 439-444, June 1991.

[5] L. F. Cooper, "A role for surface topography in creating and maintaining bone at titanium endosseous implants," J. Prosthet. Dent., vol. 84, pp. 522-534, Nov. 2000.

[6] J. E. Ellingsen, "Surface configurations of dental implants", Periodontol. 2000, vol. 17, pp. 36-46, June 1998.

[7] A. Wennerberg and T. Albrektsson, "Effects of titanium surface topography on bone integration: a systematic review," Clin. Oral Implants Res., vol. 20, Suppl 4, pp. 172-184, Sep. 2009.

[8] A. Wennerberg and T. Albrektsson, "On implant surfaces: a review of current knowledge and opinions," Int. J. Oral Maxillofac. Implants, vol. 25, pp. 63-74, Jan.-Feb. 2010.

[9] K. T. Bowers, J. C. Keller, B. A. Randolph, D. G. Wick, and C. M. Michaels, "Optimization of surface micromorphology for enhanced osteoblast responses in vitro," Int. J. Oral Maxillofac. Implants, vol. 7, pp. 302-310, 1992.

[10] K. Mustafa, J. Wroblewski, K. Hultenby, B. S. Lopez, and K. Arvidson, "Effects of titanium surfaces blasted with $\mathrm{TiO}_{2}$ particles on the initial attachment of cells derived from human mandibular bone. A scanning electron microscopic and histomorphometric analysis," Clin. Oral Implants Res., vol. 11, pp. 116-128, April 2000.

[11] P. R. Klokkevold, R. D. Nishimura, M. Adachi, and A. Caputo, "Osseointegration enhanced by chemical etching of the titanium surface. A torque removal study in the rabbit," Clin. Oral Implants Res., vol. 8, pp. 442-447, Dec. 1997.

[12] A. Piattelli, L. Manzon, A. Scarano, M. Paolantonio, and M. Piattelli, "Histologic and histomorphometric analysis of the bone response to machined and sandblasted titanium implants: an experimental study in rabbits", Int. J. Oral Maxillofac. Implants, vol. 13, pp. 805-810, Nov.-Dec. 1998.

[13] I. S. Yeo, J. S. Han, and J. H. Yang, "Biomechanical and histomorphometric study of dental implants with different surface characteristics," J. Biomed. Mater. Res. B Appl. Biomater., vol. 87, pp. 303-311, Nov. 2008.

[14] M. Roccuzzo, M. Aglietta, M. Bunino, and L. Bonino, "Early loading of sandblasted and acid-etched implants: a randomizedcontrolled double-blind split-mouth study. Five-year results," Clin. Oral Implants Res., vol. 19, pp. 148-152, Feb. 2008.

[15] A. Wennerberg, T. Albrektsson, B. Andersson, and J. J. Krol, "A histomorphometric and removal torque study of screw-shaped titanium implants with three different surface topographies," Clin. Oral Implants Res., vol. 6, pp. 24-30, March 1995.

[16] A. Wennerberg, T. Albrektsson, and J. Lausmaa, "Torque and histomorphometric evaluation of c.p. titanium screws blasted with 25- and 75-microns-sized particles of $\mathrm{Al}_{2} \mathrm{O}_{3}, "$ J. Biomed. Mater. Res., vol. 30, pp. 251-260, Feb. 1996.

[17] A. Wennerberg, C. Hallgren, C. Johansson, and S. Danelli, "A histomorphometric evaluation of screw-shaped implants each prepared with two surface roughnesses," Clin. Oral Implants Res., vol. 9, pp. 11-19, Feb. 1998.

[18] C. Larsson, P. Thomsen, B. O. Aronsson, M. Rodahl, J. Lausmaa, B. Kasemo, and L. E. Ericson, "Bone response to surface-modified titanium implants: studies on the early tissue response to machined and electropolished implants with different oxide thicknesses," Biomaterials, vol. 17, pp. 605-616, March 1996.

[19] C. J. Ivanoff, G. Widmark, C. Johansson, and A. Wennerberg, "Histologic evaluation of bone response to oxidized and turned titanium micro-implants in human jawbone," Int. J. Oral Maxillofac. Implants, vol. 18, pp. 341-348, May-June 2003.

[20] W. Zechner, S. Tangl, G. Fürst, G. Tepper, U. Thams, G. Mailath, and G. Watzek, "Osseous healing characteristics of three different implant types," Clin. Oral Implants Res., vol. 14, pp. 150-157, April 2003.

[21] R. Glauser, A. Zembic, P. Ruhstaller, and S. Windisch, "Five-year results of implants with an oxidized surface placed predominantly in soft quality bone and subjected to immediate occlusal loading," J. Prosthet. Dent., vol. 97, pp. S59-S68, June 2007.

[22] E. A. Nicu, N. Van Assche, W. Coucke, W. Teughels, and M. Quirynen, "RCT comparing implants with turned and anodically oxidized surfaces: a pilot study, a 3-year follow-up," J. Clin. Periodontol., vol. 39, pp. 1183-1190, Dec. 2012. 
[23] Y. H. Kim, J. Y. Koak, I. T. Chang, A. Wennerberg, and S. J. Heo, "A histomorphometric analysis of the effects of various surface treatment methods on osseointegration," Int. J. Oral Maxillofac. Implants, vol. 18, pp. 349-356, May-June 2003.

[24] Y. T. Sul, C. Johansson, A. Wennerberg, L. R. Cho, B. S. Chang, and T. Albrektsson, "Optimum surface properties of oxidized implants for reinforcement of osseointegration: surface chemistry, oxide thickness, porosity, roughness, and crystal structure," Int. J. Oral Maxillofac. Implants, vol. 20, pp. 349-359, May-June 2005.

[25] Y. T. Sul, C. B. Johansson, and T. Albrektsson, "Oxidized titanium screws coated with calcium ions and their performance in rabbit bone," Int. J. Oral Maxillofac. Implants, vol. 17, pp. 625-634, Sep.Oct. 2002.

[26] X. Zhu, J. L. Ong, S. Kim, and K. Kim, "Surface characteristics and structure of anodic oxide films containing $\mathrm{Ca}$ and $\mathrm{P}$ on a titanium implant material," J. Biomed. Mater. Res., vol. 60, pp. 333-338, May 2002.

[27] B. Al-Nawas, K. A. Groetz, H. Goetz, H. Duschner, and W. Wagner, "Comparative histomorphometry and resonance frequency analysis of implants with moderately rough surfaces in a loaded animal model," Clin. Oral Implants Res., vol. 19, pp. 1-8, Jan. 2008.

[28] J. W. Koh, J. H. Yang, J. S. Han, J. B. Lee, and S. H. Kim, "Biomechanical evaluation of dental implants with different surfaces: Removal torque and resonance frequency analysis in rabbits," J. Adv. Prosthodont., vol. 1, pp. 107-112, July 2009.

[29] R. Z. LeGeros, "Properties of osteoconductive biomaterials: calcium phosphates," Clin. Orthop. Relat. Res., pp. 81-98, Feb. 2002.

[30] L. Sun, C. C. Berndt, K. A. Gross, and A. Kucuk, "Material fundamentals and clinical performance of plasma-sprayed hydroxyapatite coatings: a review," J. Biomed. Mater. Res., vol. 58, pp. 570-592, 2001.

[31] H. S. Alghamdi, V. M. Cuijpers, J. G. Wolke, J. J. van den Beucken, and J. A. Jansen, "Calcium-phosphate-coated oral implants promote osseointegration in osteoporosis," J. Dent. Res., vol. 92, pp. 982-988, Nov. 2013.

[32] J. W. Koh, Y. S. Kim, J. H. Yang, and I. S. Yeo, "Effects of a calcium phosphate-coated and anodized titanium surface on early bone response," Int. J. Oral Maxillofac. Implants, vol. 28, pp. 790797, May-June 2013.

[33] S. Saber-Samandari, K. Alamara, and K. A. Gross, "Micro-Raman spectroscopy shows how the coating process affects the characteristics of hydroxylapatite," Acta Biomater., vol. 9, pp. 9538-9546, Dec. 2013.

[34] R. A. Surmenev, M. A. Surmeneva, and A. A. Ivanova, "Significance of calcium phosphate coatings for the enhancement of new bone osteogenesis - A review," Acta Biomater., vol. 10, pp. 557-579, Feb. 2014

[35] C. You, I. S. Yeo, M. D. Kim, T. K. Eom, J. Y. Lee, and S. Kim, "Characterization and in vivo evaluation of calcium phosphate coated cp-titanium by dip-spin method," Curr. Appl. Phys., vol. 5, pp. 501-506, July 2005.

[36] J. J. Lee, L. Rouhfar, and O. R. Beirne, "Survival of hydroxyapatite-coated implants: a meta-analytic review," J. Oral Maxillofac. Surg., vol. 58, pp. 1372-1379; discussion 1379-1380, Dec. 2000

[37] B. A. van Oirschot, E. M. Bronkhorst, J. J. van den Beucken, G. J. Meijer, J. A. Jansen, and R. Junker, "Long-term survival of calcium phosphate-coated dental implants: a meta-analytical approach to the clinical literature," Clin. Oral Implants Res., vol. 24, pp. 355362, April 2013.

[38] S. F. Lamolle, M. Monjo, S. P. Lyngstadaas, J. E. Ellingsen, and H. J. Haugen, "Titanium implant surface modification by cathodic reduction in hydrofluoric acid: surface characterization and in vivo performance," J. Biomed. Mater. Res. A, vol. 88, pp. 581-588, March 2009

[39] L. F. Cooper, Y. Zhou, J. Takebe, J. Guo, A. Abron, A. Holmén, and J. E. Ellingsen, "Fluoride modification effects on osteoblast behavior and bone formation at $\mathrm{TiO}_{2}$ grit-blasted c.p. titanium endosseous implants," Biomaterials, vol. 27, pp. 926-936, Feb. 2006.

[40] S. F. Lamolle, M. Monjo, M. Rubert, H. J. Haugen, S. P. Lyngstadaas, and J. E. Ellingsen, "The effect of hydrofluoric acid treatment of titanium surface on nanostructural and chemical changes and the growth of MC3T3-E1 cells," Biomaterials, vol. 30, pp. 736-742, Feb. 2009.

[41] S. F. Taxt-Lamolle, M. Rubert, H. J. Haugen, S. P. Lyngstadaas, J. E. Ellingsen, and M. Monjo, "Controlled electro-implementation of fluoride in titanium implant surfaces enhances cortical bone formation and mineralization," Acta Biomater., vol. 6, pp. 10251032, March 2010.

[42] H. De Bruyn, F. Raes, L. F. Cooper, G. Reside, J. S. Garriga, L. G. Tarrida, J. Wiltfang, and M. Kern, "Three-years clinical outcome of immediate provisionalization of single Osseospeed $\left({ }^{\mathrm{TM}}\right)$ implants in extraction sockets and healed ridges", Clin. Oral Implants Res., vol. 24, pp. 217-223, Feb. 2013.

[43] C. Mertens and H. G. Steveling, "Early and immediate loading of titanium implants with fluoride-modified surfaces: results of 5-year prospective study," Clin. Oral Implants Res., vol. 22, pp. 13541360, Dec. 2011.

[44] R. M. Palmer, L. C. Howe, P. J. Palmer, and R. Wilson, "A prospective clinical trial of single Astra Tech 4.0 or 5.0 diameter implants used to support two-unit cantilever bridges: results after 3 years," Clin. Oral Implants Res., vol. 23, pp. 35-40, Jan. 2012.

[45] J. Y. Choi, H. J. Lee, J. U. Jang, and I. S. Yeo, "Comparison between bioactive fluoride modified and bioinert anodically oxidized implant surfaces in early bone response using rabbit tibia model," Implant Dent., vol. 21, pp. 124-128, April 2012.

[46] R. Jimbo, R. Anchieta, M. Baldassarri, R. Granato, C. Marin, H. S. Teixeira, N. Tovar, S. Vandeweghe, M. N. Janal, and P. G. Coelho, "Histomorphometry and bone mechanical property evolution around different implant systems at early healing stages: an experimental study in dogs," Implant Dent., vol. 22, pp. 596-603, Dec. 2013.

[47] U. W. Jung, J. Y. Choi, C. S. Kim, K. S. Cho, J. K. Chai, C. K. Kim, and S. H. Choi, "Evaluation of mandibular posterior single implants with two different surfaces: a 5-year comparative study," J. Periodontol., vol. 79, pp. 1857-1863, Oct. 2008.

[48] H. S. Pak, I. S. Yeo, and J. H. Yang, "A histomorphometric study of dental implants with different surface characteristics," $J$. Adv Prosthodont., vol. 2, pp. 142-147, Dec. 2010.

[49] I. S. Yeo, S. K. Min, and Y. An, "Influence of Bioactive Material Coating of Ti Dental Implant Surfaces on Early Healing and Osseointegration of Bone," J. Kor. Phys. Soc., vol. 57, pp. 17171720, Dec. 2010.

[50] R. Jimbo, D. Ono, Y. Hirakawa, T. Odatsu, T. Tanaka, and T. Sawase, "Accelerated photo-induced hydrophilicity promotes osseointegration: an animal study," Clin. Implant Dent. Relat. Res., vol. 13, pp. 79-85, March 2011.

[51] K. H. Park, J. Y. Koak, S. K. Kim, C. H. Han, and S. J. Heo, "The effect of ultraviolet-C irradiation via a bactericidal ultraviolet sterilizer on an anodized titanium implant: a study in rabbits," Int. J. Oral Maxillofac. Implants, vol. 28, pp. 57-66, Jan.-Feb. 2013.

[52] A. Wennerberg, R. Jimbo, S. Stübinger, M. Obrecht, M. Dard, and S. Berner, "Nanostructures and hydrophilicity influence osseointegration: a biomechanical study in the rabbit tibia," Clin. Oral Implants Res., vol. 25, pp. 1041-1050, Sep. 2014.

[53] M. M. Bornstein, P. Valderrama, A. A. Jones, T. G. Wilson, R. Seibl, and D. L. Cochran, "Bone apposition around two different sandblasted and acid-etched titanium implant surfaces: a histomorphometric study in canine mandibles," Clin. Oral Implants Res., vol. 19, pp. 233-241, March 2008.

[54] D. Buser, N. Broggini, M. Wieland, R. K. Schenk, A. J. Denzer, D. L. Cochran, B. Hoffmann, A. Lussi, and S. G. Steinemann, "Enhanced bone apposition to a chemically modified SLA titanium surface," J. Dent. Res., vol. 83, pp. 529-533, July 2004.

[55] I. Wall, N. Donos, K. Carlqvist, F. Jones, and P. Brett, "Modified titanium surfaces promote accelerated osteogenic differentiation of mesenchymal stromal cells in vitro," Bone, vol. 45, pp. 17-26, July 2009.

[56] F. Schwarz, M. Herten, M. Sager, M. Wieland, M. Dard, and J. Becker, "Bone regeneration in dehiscence-type defects at chemically modified (SLActive) and conventional SLA titanium implants: a pilot study in dogs," J. Clin. Periodontol., vol. 34, pp. 78-86, Jan. 2007.

[57] R. Liu, T. Lei, V. Dusevich, X. Yao, Y. Liu, M. P. Walker, Y. Wang, and L. Ye, "Surface characteristics and cell adhesion: a comparative study of four commercial dental implants," $J$. Prosthodont., vol. 22, pp. 641-651, Dec. 2013. 
[58] E. A. Bonfante, M. N. Janal, R. Granato, C. Marin, M. Suzuki, N. Tovar, and P. G. Coelho, "Buccal and lingual bone level alterations after immediate implantation of four implant surfaces: a study in dogs," Clin. Oral Implants Res., vol. 24, pp. 1375-1380, Dec. 2013.

[59] J. B. Gomes, F. E. Campos, C. Marin, H. S. Teixeira, E. A. Bonfante, M. Suzuki, L. Witek, D. Zanetta-Barbosa, and P. G. Coelho, "Implant biomechanical stability variation at early implantation times in vivo: an experimental study in dogs," Int. J. Oral Maxillofac. Implants, vol. 28, pp. e128-e134, May-June 2013.

[60] A. Wennerberg, S. Galli, and T. Albrektsson, "Current knowledge about the hydrophilic and nanostructured SLActive surface," Clin. Cosmet. Investig. Dent., vol. 3, pp. 59-67, Sep. 2011.

[61] S. Heberer, S. Kilic, J. Hossamo, J. D. Raguse, and K. Nelson, "Rehabilitation of irradiated patients with modified and conventional sandblasted acid-etched implants: preliminary results of a split-mouth study," Clin. Oral Implants Res., vol. 22, pp. 546551, May 2011.

[62] Z. C. Karabuda, J. Abdel-Haq, and V. Arisan, "Stability, marginal bone loss and survival of standard and modified sand-blasted, acidetched implants in bilateral edentulous spaces: a prospective 15month evaluation," Clin. Oral Implants Res., vol. 22, pp. 840-849, Aug. 2011.

[63] A. M. El-Sheikh, O. F. Shihabuddin, and S. M. Ghoraba, "A prospective study of early loaded single implant-retained mandibular overdentures: preliminary one-year results," Int. J. Dent., vol. 2012, p. 236409, 2012.

[64] A. Filippi, F. L. Higginbottom, T. Lambrecht, B. P. Levin, J. L. Meier, P. S. Rosen, B. Wallkamm, C. Will, and M. Roccuzzo, "A prospective noninterventional study to document implant success and survival of the Straumann Bone Level SLActive dental implant in daily dental practice," Quintessence Int., vol. 44, pp. 499-512, July 2013.

[65] G. Luongo and G. Oteri, "A noninterventional study documenting use and success of implants with a new chemically modified titanium surface in daily dental practice," J. Oral Implantol., vol. 36, pp. 305-314, 2010.

[66] F. Rossi, E. Ricci, C. Marchetti, N. P. Lang, and D. Botticelli, "Early loading of single crowns supported by 6-mm-long implants with a moderately rough surface: a prospective 2-year follow-up cohort study," Clin. Oral Implants Res., vol. 21, pp. 937-943, Sep. 2010.

[67] J. E. Kim, S. S. Kang, K. H. Choi, J. S. Shim, C. M. Jeong, S. W. Shin, and J. B. Huh, "The effect of anodized implants coated with combined rhBMP-2 and recombinant human vascular endothelial growth factors on vertical bone regeneration in the marginal portion of the peri-implant," Oral Surg. Oral Med. Oral Pathol. Oral Radiol., vol. 115, pp. e24-e31, June 2013.

[68] J. K. Lee, L. R. Cho, H. S. Um, B. S. Chang, and K. S. Cho, "Bone formation and remodeling of three different dental implant surfaces with Escherichia coli-derived recombinant human bone morphogenetic protein 2 in a rabbit model," Int. J. Oral Maxillofac. Implants, vol. 28, pp. 424-430, March-April 2013.

[69] S. K. Min, H. K. Kang, H. Jang da, S. Y. Jung, O. B. Kim, B. M. Min, and I. S. Yeo, "Titanium surface coating with a lamininderived functional peptide promotes bone cell adhesion," Biomed. Res. Int., vol. 2013, p. 638348, 2013.

[70] J. J. Ryu, K. Park, H. S. Kim, C. M. Jeong, and J. B. Huh, "Effects of anodized titanium with Arg-Gly-Asp (RGD) peptide immobilized via chemical grafting or physical adsorption on bone cell adhesion and differentiation," Int. J. Oral Maxillofac. Implants, vol. 28, pp. 963-972, July-Aug. 2013.

[71] H. K. Kang, O. B. Kim, S. K. Min, S. Y. Jung, H. Jang da, T. K. Kwon, B. M. Min, and I. S. Yeo, "The effect of the DLTIDDSYWYRI motif of the human laminin $\alpha 2$ chain on implant osseointegration," Biomaterials, vol. 34, pp. 4027-4037, May 2013.

[72] D. Yoo, N. Tovar, R. Jimbo, C. Marin, R. B. Anchieta, L. S Machado, J. Montclare, F. P. Guastaldi, M. N. Janal, and P. G. Coelho, "Increased osseointegration effect of bone morphogenetic protein 2 on dental implants: An in vivo study," J. Biomed. Mater. Res. A, vol. 102, pp. 1921-1927, June 2014.

[73] Q. H. Jiang, L. Liu, S. Peel, G. L. Yang, S. F. Zhao, and F. M. He "Bone response to the multilayer BMP-2 gene coated porous titanium implant surface," Clin. Oral Implants Res., vol. 24, pp. 853-861, Aug. 2013.

[74] A. J. Niehaus, D. E. Anderson, V. F. Samii, S. E. Weisbrode, J. K. Johnson, M. S. Noon, D. L. Tomasko, and J. J. Lannutti, "Effects of orthopedic implants with a polycaprolactone polymer coating containing bone morphogenetic protein-2 on osseointegration in bones of sheep," Am. J. Vet. Res., vol. 70, pp. 1416-1425, Nov. 2009.

[75] M. Chiapasco, P. Casentini, M. Zaniboni, E. Corsi, and T. Anello, "Titanium-zirconium alloy narrow-diameter implants (Straumann Roxolid $\left.\left({ }^{\circledR}\right)\right)$ for the rehabilitation of horizontally deficient edentulous ridges: prospective study on 18 consecutive patients," Clin. Oral Implants Res., vol. 23, pp. 1136-1141, Oct. 2012.

[76] B. C. Lee, I. S. Yeo, D. J. Kim, J. B. Lee, S. H. Kim, and J. S. Han, "Bone formation around zirconia implants combined with rhBMP-2 gel in the canine mandible," Clin. Oral Implants Res., vol. 24, pp. 1332-1338, Dec. 2013.

[77] B. Al-Nawas, U. Brägger, H. J. Meijer, I. Naert, R. Persson, A. Perucchi, M. Quirynen, G. M. Raghoebar, T. E. Reichert, E. Romeo, H. J. Santing, M. Schimmel, S. Storelli, C. ten Bruggenkate, B. Vandekerckhove, W. Wagner, D. Wismeijer, and F. Müller, "A double-blind randomized controlled trial (RCT) of Titanium-13Zirconium versus Titanium Grade IV small-diameter bone level implants in edentulous mandibles--results from a 1-year observation period," Clin. Implant Dent. Relat. Res., vol. 14, pp. 896-904, Dec. 2012.

[78] I. Rocchietta, F. Fontana, A. Addis, P. Schupbach, and M. Simion, "Surface-modified zirconia implants: tissue response in rabbits," Clin. Oral Implants Res., vol. 20, pp. 844-850, Aug. 2009.

() In-Sung Yeo; Licensee Bentham Open.

This is an open access article licensed under the terms of the Creative Commons Attribution Non-Commercial License (http://creativecommons.org/licenses/by-nc/3.0/) which permits unrestricted, non-commercial use, distribution and reproduction in any medium, provided the work is properly cited. 